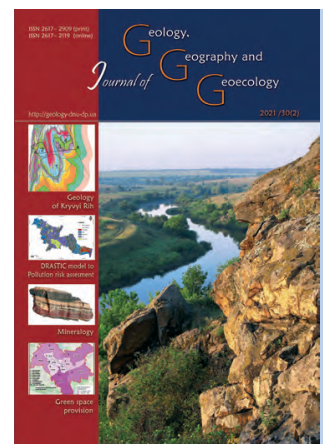

Journal of Geology.

ISSN 2617-2909 (print)

ISSN 2617-2119 (online)

Geography and

Geoecology

Journ.Geol.Geograph.

Geology,

30(2), 355-364.

Journal home page: geology-dnu.dp.ua

Ravindranath I. G., Thirukumaran V.

Journ. Geol. Geograph. Geoecology, 30(2), 355-364.

\title{
Spatial mapping for Groundwater Vulnerability to Pollution Risk Assessment Using DRASTIC Model in Ponnaiyar River Basin, South India
}

Ingershal G. Ravindranath, Venugopal Thirukumaran

Department of Geology, Govt. Arts College, Salem, Periyar University, Tamil Nadu, India, geoscienceravi@yahoo.co.in

Received: 13.11 .2020

Received in revised form: 13.03 .2021

Accepted: 14.04.2021
Abstract. Groundwater is the principle source of drinking water and protection of groundwater quality is an important issue meets out the increasing population and agricultural practices. The present research an attempt made to develop DRASTIC model to understand the groundwater contamination risk in Ponnaiyar River Basin (PRB), Tamil Nadu, India using geographical information system (GIS). GIS have been shown to be useful tools for assessing groundwater pollution hazard. According to Central Ground Water Board reports the PRB categorized by semi-critical groundwater development. In view of the extensive reliance on this basin, contamination of PRB groundwater became an alarming issue. To assess groundwater contamination risk in the PRB the parameters such as Groundwater depth, Net recharge, Aquifer media, Soil media, Topography, Impact of vadose zone and Hydraulic conductivity were selected. Based on the importance of groundwater contamination all the parameters were assigned to rank and weights. Then all the themes were integrated and classified into five categories such as very low (9.33\%), low (26.54\%), moderate (34.77\%), high (22.38\%) and very high (6.98) risk. To validate the DRASTIC model, nitrate concentration was selected and found that it is $81.53 \%$ accurate which reflects that, DRASTIC model is appropriate to understand groundwater pollution risk assessment. In the GSB groundwater is contaminated mainly due to extensive use of groundwater extraction for agriculture purpose. Groundwater risk index assessment is an effective tool for groundwater management in the PRB.

Keywords: Remote sensing, GIS, DRASTIC indeed, Groundwater vulnerability, South India

\section{Просторове картографування вразливості підземних вод до оцінки ризику забруднення 3 використанням моделі DRASTIC у басейні річки Поннаяр, Південна Індія}

\author{
І.Г. Равіндранат, В. Тірукумаран \\ Державний коледжммстеитв, університет Періяр, Салем, Тамілнад, Індія, geoscienceravi@yahoo.co.in
}

\begin{abstract}
Анотація. Підземні води є основним джерелом питної води, а захист якості підземних вод є важливим питанням, що відповідає зростаючій чисельності населення та сільськогосподарській практиці. У цьому дослідженні зроблена спроба розробити модель DRASTIC для розуміння ризику забруднення підземних вод у Поннаярському річковому басейні (ПРБ) (штат Тамілнад, Індія), використовуючи географічну інформаційну систему (ГІС). Показано, що ГІС є корисними інструментами для оцінки небезпеки забруднення підземних вод. Згідно з повідомленнями Центральної ради з питань грунтових вод, ПРБ класифікується за напівкритичним розвитком підземних вод. 3 огляду на значну залежність від цього басейну, забруднення підземних вод ПРБ стало загрозливою проблемою. Для оцінки ризику забруднення підземних вод у ПРБ були обрані такі параметри, як глибина грунтових вод, поповнення запасів, водоносний шар, грунтове середовище, топографія, вплив вадозної зони та гідравлічна провідність. Виходячи з важливості забруднення підземних вод, всім параметрам були присвоєні ранг та вага. Тоді всі показники були інтегровані та класифіковані за п'ятьма категоріями, такими як дуже низький (9,33\%), низький (26,54\%), помірний $(34,77 \%)$, високий $(22,38 \%)$ та дуже високий $(6,98)$ ризик. Для перевірки моделі DRASTIC була обрана концентрація нітратів, і було встановлено, що вона є точною на 81,53\%, що підтверджує можливість застосування моделі DRASTIC для розуміння оцінки ризику забруднення підземних вод. У GSB підземні води забруднені головним чином завдяки широкому використанню видобутку підземних вод для сільського господарства. Оцінка індексу ризику забруднення підземних вод $\epsilon$ ефективним інструментом управління підземними водами в ПРБ.
\end{abstract}




\section{Introduction}

Groundwater is one of the most valuable resources for living peoples. Due to extensive pumping, agricultural, and industrial activities, aquifers are at risk of being contaminated. Intensive application of pesticides and fertilisers, discharge of wastewater, and industrial effluent and excessive groundwater abstraction are just a few examples of activities that lead to groundwater contamination. These activities have resulted in the deterioration of water resources in various regions around the world (Pandey et al. 1999). The drastic model developed by the U.S. Environmental Protection Agency in 1985 with aiming to evaluate groundwater pollution potential for the entire USA. The word DRASTIC is an acronym formed the initial letters of the seven factors which are used for determining relative rankings. (D) refers to depth to water, (R) refers to net recharge, (A) refers to Aquifer media, $(\mathrm{S})$ refers to soil media, $(\mathrm{T})$ refers to topography, (I) refers to impact of the vadose zone media, and (C) refers to hydraulic conductivity of the aquifer (Aller et al.,1987) It is very common to use intrinsic vulnerability either alone or coupled with other factors to assess groundwater contamination risk. The most widely used method for intrinsic vulnerability assessment is the DRASTIC approach (Aller et al. 1985). A calibrated drastic model was used to predict the intrinsic vulnerability as well as the groundwater pollution risk (Shahid, 2000;Smail, 2014; Kazakis and Voudouris, 2015; Mfumu Kihumba et al.,2017).Ahirwar and Shukla (2018) assessed the groundwater vulnerability in Upper Betwa River watershed using GIS based DRASTIC model. The revealed that high vulnerable zone located in unsuitable of nitrate concentration in groundwater. It is proved that DRASTIC model is one the suitable model for groundwater contamination.

DRASTIC is a standardized system, for assessing ground water pollution potential using hydrogeologic setting (Sahu and Nandi,2015).In groundwater context, risk can be defined as the probability that groundwater at a drinking well becomes contaminated to an unacceptable level by activities on the land surface(Morris and Foster 1998). Baalousha (2011) conducted a case study on mapping groundwater contamination risk using GIS and groundwater modeling in Gaza Strip at Palestine. The results show that area o highest contamination risk occurs in the southern cities of Khan Yunis and Rafah. Remote sensing and Geographical Information System (GIS) has been widely used in risk mapping (Al-Adamat et al. 2003; Mimi and Assi 2009).Groundwater vulnerability map for the Kherran plain designed to demonstrate areas of maximum potential for groundwater pollution based on hydro-geological state and human impacts. (Chitsazan and Akhtari, 2009). A vulnerability map for the Ordos Plateau has been designed to demonstrate the areas of the maximum potential for groundwater pollution based on hydrogeological conditions (Yin, 2013). Venkatesan et al. (2019) explained the groundwater vulnerability using GIS a DRASTIC model for Upper Palar River basin, Tamil Nadu. The result of the study shows that, $50 \%$ of the study area falls under very high pollution potential zones. The very high vulnerability class, which is covered by the alluvium along the river course, is most likely to pollution due to the very lower slope terrains in the direction of central part which allows better percolation of contaminants into the groundwater. In this study, a new approach is proposed for contamination risk mapping. This approach depends on the idea that groundwater contamination risk is a product of probability of contamination occurring and contamination impact.

\section{Study Area}

The study area Ponnaiyar River basin extends over approximately of $11,595 \mathrm{sq} . \mathrm{km}$, and lies between $11^{\circ} 350$ and $12^{\circ} 35^{\prime} 0^{\prime \prime} \mathrm{N}$ latitudes and $77^{\circ} 45^{\prime} 0^{\prime \prime}$ ' and $79^{\circ} 55^{\prime} 0 "$ E longitudes (Fig. 1). Ponnaiyar River originates on the southeastern slopes of Chennakesava Hills, northwest of Nandidurg of Kolar district in Karnataka State at an altitude of $1000 \mathrm{~m}$ above mean sea level (amsl). The total length of Ponnaiyar River is $432 \mathrm{~km}$ of which $85 \mathrm{~km}$ lies in Karnataka state, 187 $\mathrm{km}$ in Dharmapuri, Krishnagiri and Salem districts, $54 \mathrm{~km}$ in Thiruvannamalai and Vellore districts and $106 \mathrm{~km}$ in Cuddalore and Villupuram districts of Tamil Nadu. The Ponnaiyar basin is predominantly built up with granite and gneisses rocks of Archean period. The granite is of very good quality and extensive outcrops and masses of it are commonly found. The chief components of rocks are hornblende and feldspar. Foliation is seldom seen. In the plains of reserve forest, quartz is found commonly. The diamond granite is also found in scattered pockets in the area of Chitteri hills in Dharmapuri and Krishnagiri sub-divisions. Charnockite rocks of Archean period are also seen in some areas. Alluvium and sand dunes of quaternary period are also seen at a few places. The 15 years (2000-2014) average annual rainfall in the basin is $969 \mathrm{~mm}$. The catchment falls under the tropical belt. The climate in general is hot; April and May being the hottest months of the year when the temperature rises to $34^{\circ} \mathrm{C}$. 


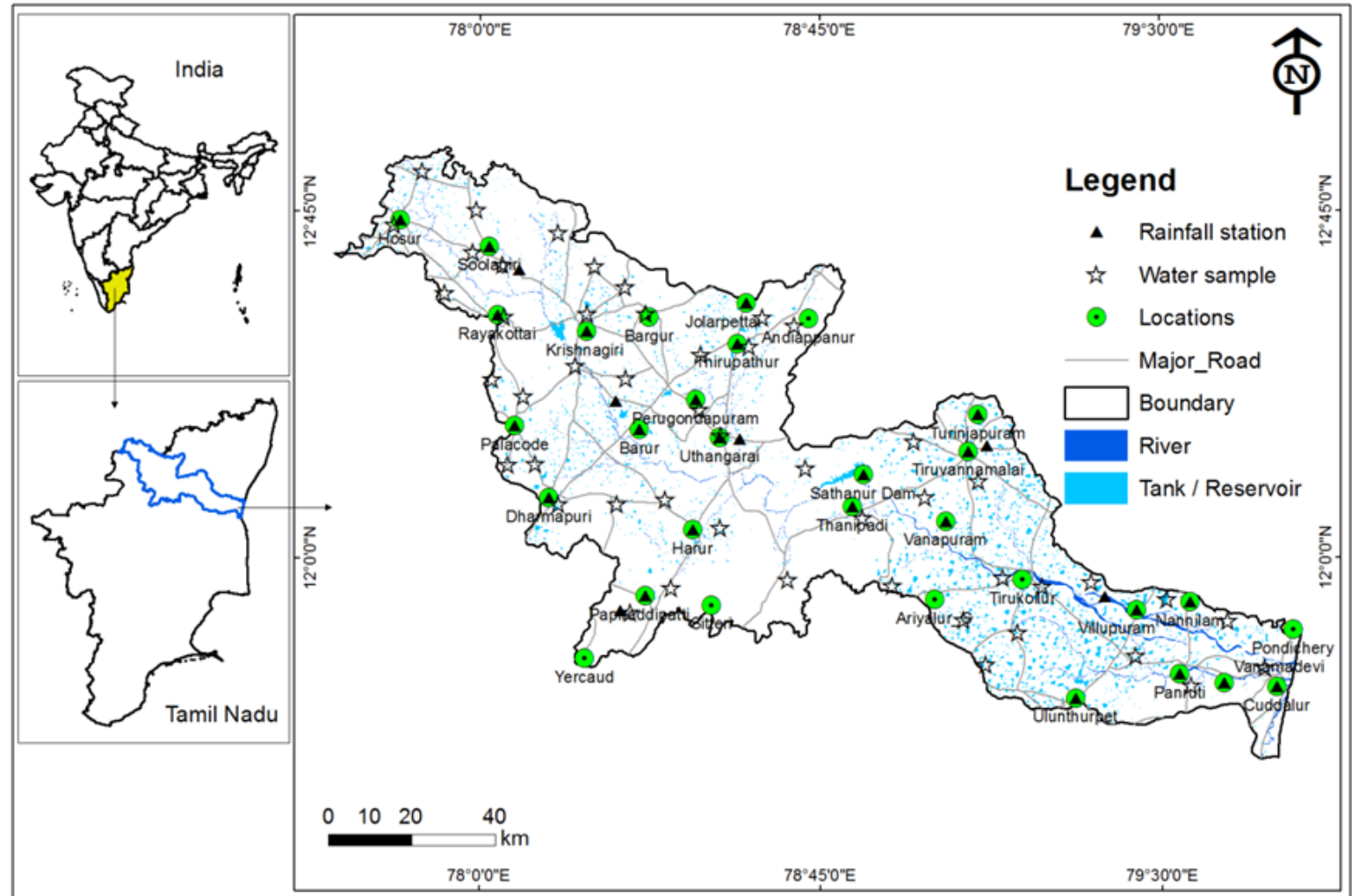

Fig. 1 Location of the study area Ponnaiyar River Basin shows the Rainfall station, water sample location for water level and groundwater quality.

\section{Methodology}

The DRASTIC model consist of seven parameter based on the previous literature such as D-depth to water, R-recharge, A-aquifer media, S-soil media, T-topography, I- impact of the vadose zone, and Chydraulic conductivity. The system contains three parts such as ratings, ranges, and weights. Every drastic parameter has been assigned a relative weight between 1 to 5 , with 5 being considered most significant and 1 being considered least significant regarding contamination potential. Moreover, each parameter has been assigned a rating according to range between 1 and 10, which depends upon the influence of pollution concentration.

\section{DRASTIC parameters}

\section{Depth to water level (D)}

There are 48 water level sample has been collected during the pre-monsoon season, June 2018 for estimation of groundwater depth. The maximum and minimum water level depths measured in the watershed are $26 \mathrm{~m}$ and $3.5 \mathrm{~m}$ below ground level (bgl) respectively. This point data were contoured by interpolating and divided into five classes. Areas with shallow water table depth are more vulnerable because pollutants have to pass the shortest distance to join the water table. The deeper water table levels imply lesser chance for contamination to occur. The depth to water table map was then classified into ranges defined by the DRASTIC model and assigned rates ranging from
1 (minimum impact on vulnerability) to 10 (maximum impact on the vulnerability) and index was calculated by multiplication of weight (5) to ratings for each range which is shown (Fig.2).

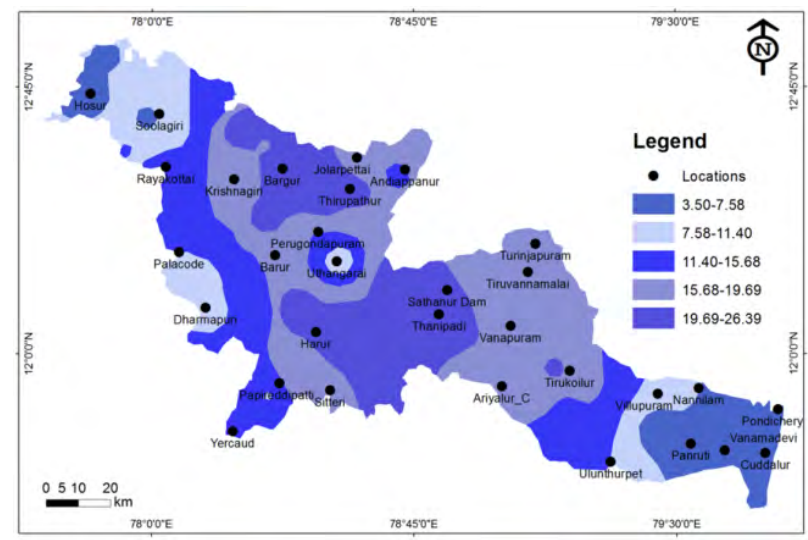

Fig. 2. Groundwater depth spatial distributions in the study area

\section{Net Recharge (R)}

Net-Recharge is the amount of water which penetrates the ground surface and reaches the water table, recharge water represents the medium for transporting pollutants. Recharge water thus available to transport a contaminant vertically to the water table and horizontally within the aquifer. The present study, Sehgal (1973) formula, utilized for net recharge from rainfall. The formula is

$$
\mathrm{W}=12.6(\mathrm{P}-406.4)^{0.5}
$$


The spatial distributions of the net recharge are shown in Figure 3. The rank and weights are assigned based on the importance.

\section{Aquifer Media (A)}

Aquifer media refers to consolidated or unconsolidated rocks serve that as an aquifer. It is the saturated zone material, which controls the

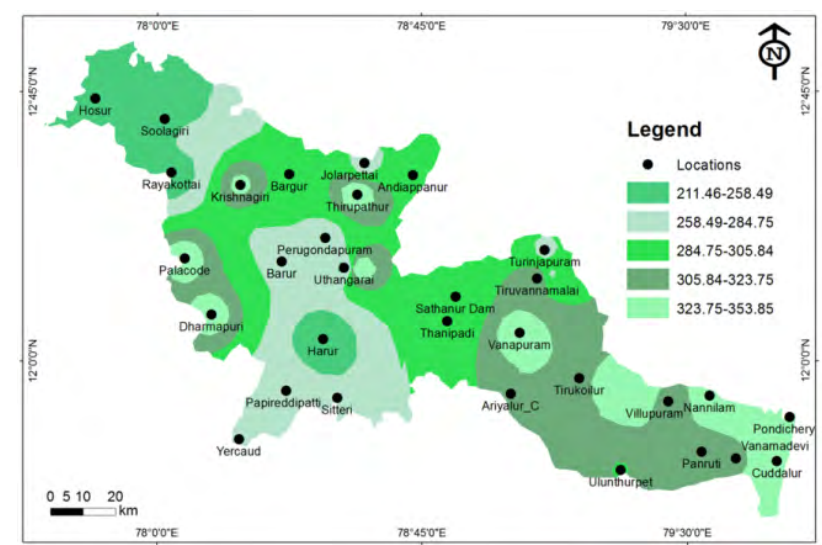

Fig. 3 Net recharge calculated from average annual rainfall for the study area

pollution attenuation processes which determine the flow rates and types of contamination. There are thirteen lithological features covered in the study area. The assigned rating for aquifer media is found to be in the range, rating and index were calculated by multiplication of weight (3) to rating for each range which is shown in (Fig.4).

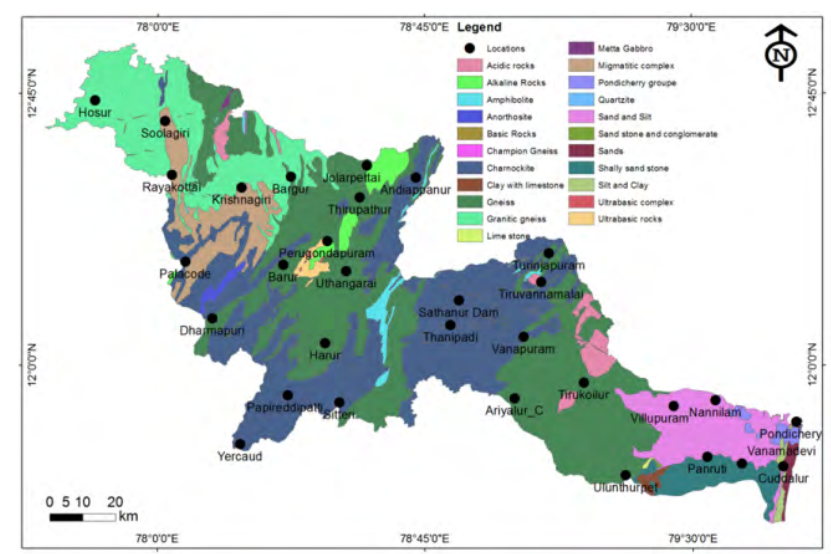

Fig. 4 Aquifer media in the study area

\section{Soil Media (S)}

Soil media refers to the weathered portion of the earth surface characterized by considerable biological activity. The soil types mostly affect soil act as transport media for contaminants to travel vertically into the groundwater because, of its ability to infiltrate impurities through rainfall recharge. Soil pollution potential. Soil types were analyzed and identified from different sampling stations using soil texture analysis. Based on soil order, the soil categories is alfisols, entisols, inceptisol, vertisols, 358 hill soil, Pondicherry group and reserved forest. The rating value of 6 was the greatest in the study area. This result was then compiled into a soil media map as an index. The range, rating and index of soil media of the study area are given in Figure 5.

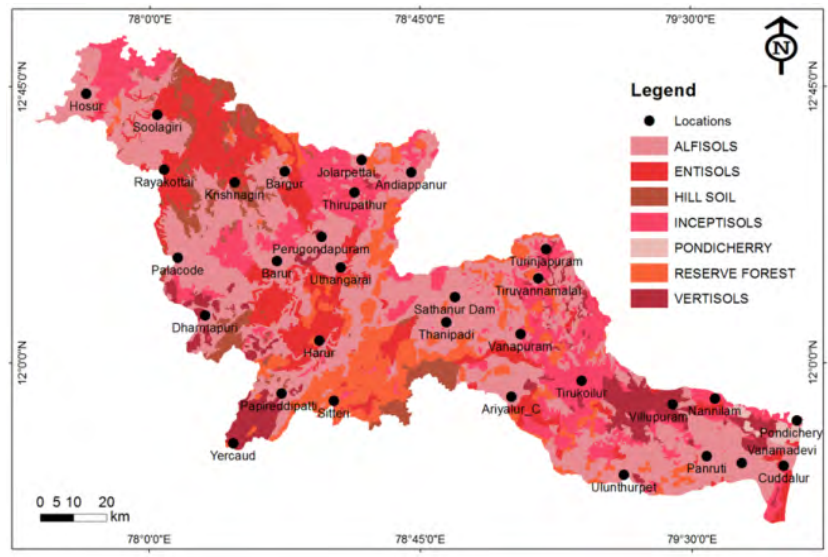

Fig. 5 Soil order in the study area

\section{Topography (T)}

Topography refers to the slope and slope variability of the land surface. Topography helps control the likelihood that a pollutant will run off or remain on the surface for long to infiltrate. Therefore, the greater the change of infiltration, the higher the pollution potential associated with the slope. Topography influences soil development and therefore has an effect on attenuation. Topography is also significant from the standpoint that the gradient and direction of flow are controlled by topography. Generally, steeper slopes signify high surface runoff. The details of slope classes are given in Figure 6.

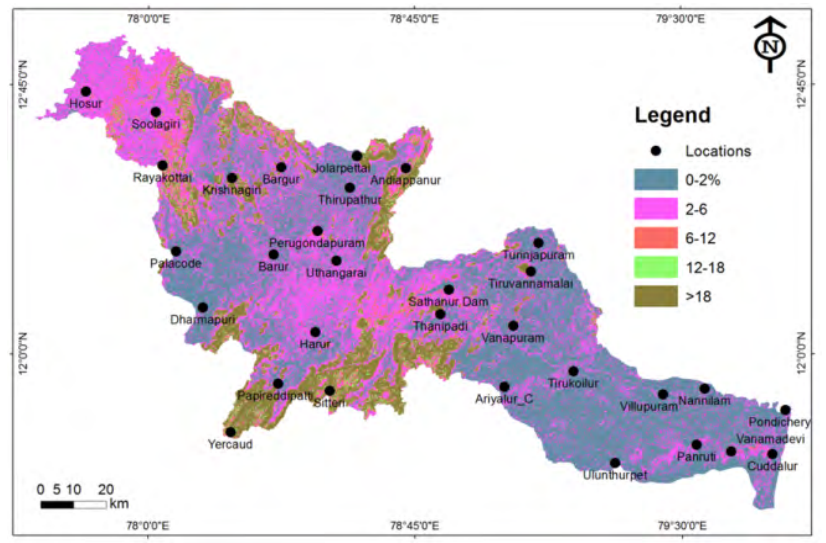

Fig. 6 Topography in the study area

\section{Impact of Vadose Zone (I)}

The vadose zone is defined as the zone above the water table which is unsaturated. When evaluating a confined aquifer, the «impact" of the vadose zone is expanded to include in the case of a confined aquifer, the significantly restrictive zone above the aquifer which forms the confining layer is used as the type of media which has the most significant impact. The 
type of vadose zone media determines the attenuation characteristics of the material below the typical, soil horizon and above the water table. The materials at the top of the vadose zone also exert an influence on soil development. The details of vadose zone classes are shown in Figure 7.

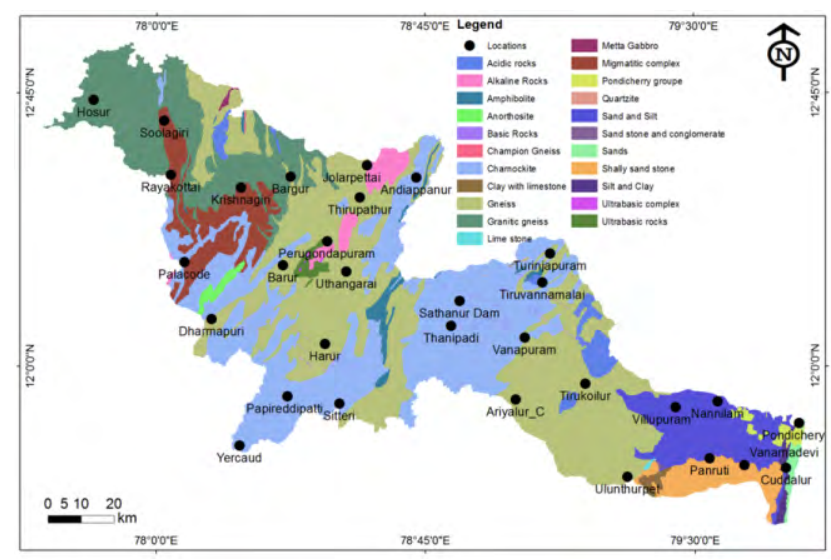

Fig. 7 Impact of vadose zone in the study area

\section{Hydraulic Conductivity (C)}

Hydraulic conductivity refers to the ability of the aquifer materials to transmit water, which in turn, controls the rate at which groundwater will flow under a given hydraulic gradient. The rate at which the ground water flows also controls the rate at which a contaminant will be moved away from the point at which it enters the aquifer. Hydraulic conductivity is controlled by the amount and interconnection of void space within the aquifer which may occur as a consequence of factors such as inter-granular porosity, fracturing and bedding planes. Hydraulic conductivity values for different soil medium determined by Ritzema (2006) have been used in the study (Table 1). The details of Hydraulic conductivity classes are shown in Figure 8.

Table 1. Hydraulic conductivity: K-value range by soil texture (Ritzema, 2006)

\begin{tabular}{|l|l|l|}
\hline S.No & Texture & $\begin{array}{l}\text { Hydraulic } \\
\text { conductivity, } \mathrm{K} \\
\text { (m.day-1) }\end{array}$ \\
\hline 1 & Gravelly coarse sand & $10-50$ \\
\hline 2 & Medium sand & $1-5$ \\
\hline 3 & Sandy loam, fine sand & $1-3$ \\
\hline 4 & $\begin{array}{l}\text { Loam, clay loam, clay (well } \\
\text { structured) }\end{array}$ & $0.5-2$ \\
\hline 5 & Very fine sandy loam & $0.2-0.5$ \\
\hline 6 & $\begin{array}{l}\text { Clay loam, clay (poorly } \\
\text { Structured) }\end{array}$ & $0.002-0.2$ \\
\hline 7 & $\begin{array}{l}\text { Dense clay (no cracks, } \\
\text { pores) }\end{array}$ & $<0.002$ \\
\hline
\end{tabular}

\section{DRASTIC Index}

In the present study, the DRASTIC method, for evaluating groundwater pollution potential was used. The DRASTIC model is used in many countries because the input information required for its application is readily available. The model was developed for the purpose of GW protection in the United States of America (USA) and its

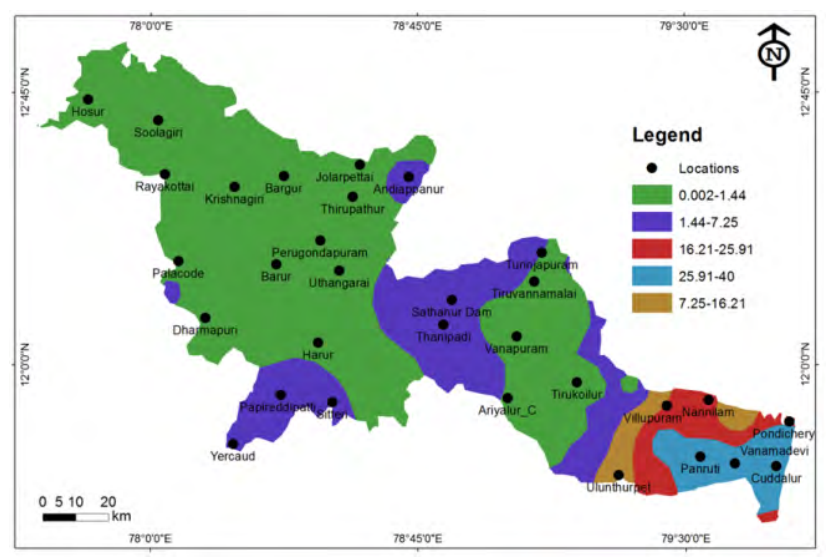

Fig.8 Hydraulic conductivity in the study area

methodology is referred as "DRASTIC" (Rahman, 2008). A numerical ranking system to assess ground water pollution potential in hydrologic settings has been devised using the DRASTIC factors. The system contains three significant parts i.e. weights, ranges and ratings. DRASTIC model evaluates the intrinsic vulnerability (Di) of groundwater in term of DRASTIC index using formula

DRASTIC Index $(\mathrm{Di})=\mathrm{DrDw}+\mathrm{RrRw}+\mathrm{ArAw}$ $+\mathrm{SrSw}+\mathrm{TrTw}+\mathrm{IrIw}+\mathrm{CrCw}$

Where, D- depth to water, R- net-recharge, Aaquifer media, S-soil media, T- topography, I- impact of Vadose zone, and C- hydraulic conductivity are the parameters, " $\mathrm{r}$ " is the rating value, and " $\mathrm{w}$ " the weight assigned to each parameter.

Each DRASTIC factor has been evaluated with respect to the other to determine the relative importance of each factor. Each DRASTIC has been assigned a relative weight ranging from 1 to 5 (Table 2). The most significant factors have weights of 5; the least significant, a weight of 1 . This exercise was accomplished by using a Delphi (consensus) approach. These weights are a constant and may not be changed. Each DRASTIC factors have been divided into ranges/classes which have an impact on pollution potential. Each range for each DRASTIC factor has been evaluated with respect to the others to determine the relative significance of each range with respect to pollution potential. The range for each DRASTIC factor has been assigned a rating which varies between 1 to 10 (Table 3). The DRASTIC model is based on seven parameters, corresponding to seven layers to be used as input parameters for modeling. 
Table 2. Assigned weight for DRASTIC parameters (Aller, 1985)

\begin{tabular}{|l|l|c|}
\hline $\begin{array}{l}\text { Factors/ } \\
\text { Hydrological } \\
\text { settings }\end{array}$ & Description & $\begin{array}{l}\text { Relative } \\
\text { weights }\end{array}$ \\
\hline Depth to water level & $\begin{array}{l}\text { It is depth from ground to water table, deeper the water table lesser will be the chances of } \\
\text { pollutions to interact with ground water. }\end{array}$ & 5 \\
\hline Net Recharge & $\begin{array}{l}\text { It is the amount of water/unit area of land that penetrates the ground surface and reaches the } \\
\text { water table, it is the reporting agents for pollutants to the ground water. }\end{array}$ & 4 \\
\hline Aquifer media & $\begin{array}{l}\text { It is the potential area for water storage, the contaminant attenuation of aquifer depends on } \\
\text { the amount and sorting of fine grains, lower the grain size higher the attenuation capacity of } \\
\text { aquifer media. }\end{array}$ & $\begin{array}{l}\text { Soil media is the uppermost and weathered part of the ground, soil cover characteristics } \\
\text { influence the surface and downward movement of contaminants }\end{array}$ \\
\hline Soil media & $\begin{array}{l}\text { It refers to slope or steepness, areas with low slope tend to retain water for longer, this } \\
\text { allows a greater infiltration of recharge of water and a greater potential for contaminant } \\
\text { migration and vulnerable to ground water contamination and vice versa. }\end{array}$ & 2 \\
\hline Topography & $\begin{array}{l}\text { It is the ground portion found between the aquifer and the soil cover in which pores or joints } \\
\text { are unsaturated, its influence on aquifer pollution potential similar to that of soil cover, } \\
\text { depending on its permeability, and on the attenuation characteristics of the media. }\end{array}$ & 5 \\
\hline $\begin{array}{l}\text { Impact of Vadose } \\
\text { zone }\end{array}$ & $\begin{array}{l}\text { It refers to the ability of the aquifer formation to transmit water; an aquifer with high } \\
\text { conductivity is vulnerable to substantial contamination as a plume of contamination can } \\
\text { move easily through the aquifer. }\end{array}$ & 3 \\
\hline $\begin{array}{l}\text { Hydraulic } \\
\text { conductivity }\end{array}$ & 5 \\
\hline
\end{tabular}

\section{Results and Discussion}

The DRASTIC index was calculated by combining all seven layers in the ArcGIS environment to delineate the groundwater vulnerability zones shown as the groundwater vulnerability map have been divided into five vulnerable zones. The very low vulnerable zones ranging from 55 to 80 DRASTIC index with a geographical area of about 1082 sq.km, low vulnerable zones ranging from 80 to 105 DRASTIC index with a geographical area of about 3077 sq.km,moderate vulnerable zones ranging from 105 to 131 with 4032 sq. km geographical area, high vulnerable zones ranging from 131 to 156 DRASTIC index with a geographical area of about 2595 sq.km and very high vulnerable zones with DRASTICindex

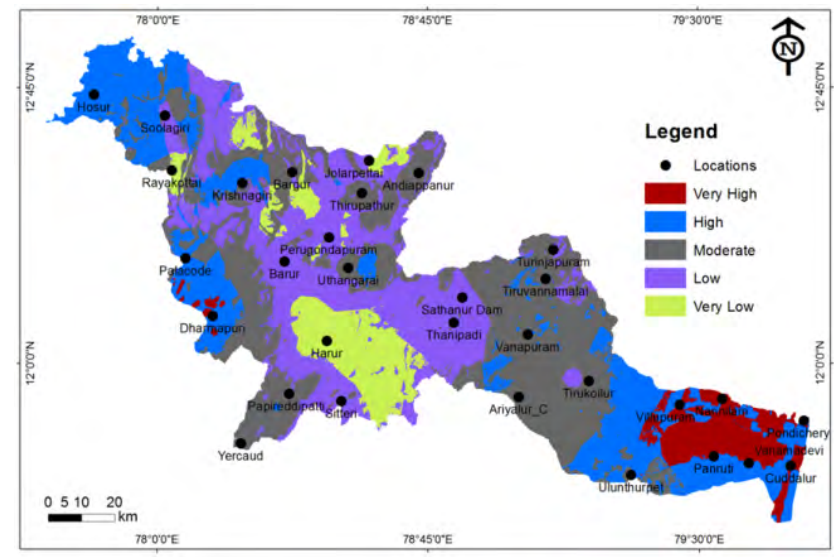

Fig. 9 DRASTIC index in the study area ranging from 156 to 182 with 809 sq. km area (Fig. 9).

According to the vulnerability map, about $3.98 \%$ of the study area falls under very high vulnerability class which is close to the coastal area; this is most likely due to the very lower slope terrains in the direction of the eastern part, which is predominantly covered with alluvium, and which allows better percolation of contaminants into the groundwater (Table 4). About $22.38 \%$ of the area falls under high vulnerblearea, this is owing to lower slope terrain sand mainly covered with sandy loam and loam which allows percolation of contaminants to the groundwater. about $34.77 \%$ of the area falls under moderate vulnerable area, this is probably because of somewhat high elevation terrains, which is covered with silty loam, where pollution is in moderate range in this area and $26.54 \%$ of the area falls under low and very low vulnerable area, this is probably due to very high slope terrains, which is covered with clay, so pollution is in very low range in this area.

\section{Validation}

The Groundwater vulnerability map was validated with nitrate concentration in groundwater as shown in (Fig.10). Results of validation have shown that in the low vulnerable zone, no nitrate contamination has been recorded. While in the moderate zone nitrate has been found in the range of up to $46 \mathrm{mg} / \mathrm{l}$. However, in high vulnerable zone, up to $110 \mathrm{mg} / \mathrm{l}$ of nitrate 
Table 3. DRASTIC model used for rank and weight assignment

\begin{tabular}{|c|c|c|c|c|}
\hline Factors & Classes & Rank & Weight & Index \\
\hline \multirow{5}{*}{ Groundwater depth (m, bgl) (D) } & $03.50-07.58$ & 10 & 5 & 50 \\
\hline & $07.58-11.40$ & 8 & & 40 \\
\hline & $11.40-15.68$ & 6 & & 30 \\
\hline & $15.68-19.69$ & 4 & & 20 \\
\hline & $19.69-26.39$ & 1 & & 5 \\
\hline \multirow[t]{5}{*}{ Net Recharge (mm/year) (R) } & $211.46-258.49$ & 1 & 4 & 4 \\
\hline & $258.49-284.75$ & 3 & & 12 \\
\hline & $284.75-305.84$ & 5 & & 20 \\
\hline & $305.84-323.75$ & 8 & & 32 \\
\hline & $323.75-353.85$ & 10 & & 40 \\
\hline \multirow[t]{22}{*}{ Aquifer media (A) } & Gneiss & 5 & 3 & 15 \\
\hline & Charnockite & 6 & & 18 \\
\hline & Granitic gneiss & 9 & & 27 \\
\hline & Metta Gabbro & 10 & & 30 \\
\hline & Basic Rocks & 5 & & 15 \\
\hline & Amphibolite & 6 & & 18 \\
\hline & Migmatitic complex & 4 & & 12 \\
\hline & Acidic rocks & 6 & & 18 \\
\hline & Champion Gneiss & 7 & & 21 \\
\hline & Alkaline Rocks & 3 & & 9 \\
\hline & Ultrabasic rocks & 6 & & 18 \\
\hline & Ultrabasic complex & 7 & & 21 \\
\hline & Quartzite & 10 & & 30 \\
\hline & Anorthosite & 5 & & 15 \\
\hline & Sand and Silt & 4 & & 12 \\
\hline & Pondicherry group & 2 & & 6 \\
\hline & Sands & 3 & & 9 \\
\hline & Silt and Clay & 1 & & 3 \\
\hline & Shally sand stone & 2 & & 6 \\
\hline & Lime stone & 1 & & 3 \\
\hline & Sand stone and conglomerate & 1 & & 3 \\
\hline & Clay with limestone & 1 & & 3 \\
\hline \multirow[t]{7}{*}{ Soil Media (S) } & Entisols & 1 & 2 & 2 \\
\hline & Alfisols & 5 & & 10 \\
\hline & Inceptisols & 7 & & 14 \\
\hline & Vertisols & 10 & & 20 \\
\hline & Reserved forest & 1 & & 2 \\
\hline & Hill soil & 6 & & 12 \\
\hline & Pondicherry group & 2 & & 4 \\
\hline \multirow[t]{5}{*}{ Topography (T) } & $0-2 \%$ & 10 & 1 & 10 \\
\hline & $2-6 \%$ & 9 & & 9 \\
\hline & $6-12 \%$ & 6 & & 6 \\
\hline & $12-18 \%$ & 3 & & 3 \\
\hline & $>18 \%$ & 1 & & 1 \\
\hline \multirow[t]{22}{*}{ Impact of Vadose Zone (I) } & Gneiss & 5 & 5 & 25 \\
\hline & Charnockite & 6 & & 30 \\
\hline & Granitic gneiss & 9 & & 45 \\
\hline & Metta Gabbro & 10 & & 50 \\
\hline & Basic Rocks & 5 & & 25 \\
\hline & Amphibolite & 6 & & 30 \\
\hline & Migmatitic complex & 4 & & 20 \\
\hline & Acidic rocks & 6 & & 30 \\
\hline & Champion Gneiss & 7 & & 35 \\
\hline & Alkaline Rocks & 3 & & 15 \\
\hline & Ultrabasic rocks & 6 & & 30 \\
\hline & Ultrabasic complex & 7 & & 35 \\
\hline & Quartzite & 10 & & 50 \\
\hline & Anorthosite & 5 & & 25 \\
\hline & Sand and Silt & 4 & & 20 \\
\hline & Pondicherry group & 2 & & 10 \\
\hline & Sands & 3 & & 15 \\
\hline & Silt and Clay & 1 & & 5 \\
\hline & Shally sand stone & 2 & & 10 \\
\hline & Lime stone & 1 & & 5 \\
\hline & Sand stone and conglomerate & 1 & & 5 \\
\hline & Clay with limestone & 1 & & 5 \\
\hline \multirow{5}{*}{ Hydraulic Conductivity $\mathrm{cm} /$ day $\mathrm{C}$} & $0-5 \mathrm{~m} / \mathrm{day}$ & 1 & 3 & 3 \\
\hline & $5-10$ & 4 & & 12 \\
\hline & 16-Oct & 5 & & 15 \\
\hline & $16-24$ & 8 & & 24 \\
\hline & $24-42$ & 10 & & 30 \\
\hline
\end{tabular}


Table 4. DRASTIC model index area and their percentage

\begin{tabular}{|r|l|l|r|r|}
\hline \multicolumn{1}{|l|}{ ID } & drastic & Index & \multicolumn{1}{|l|}{ Area } & \multicolumn{1}{l|}{$\%$} \\
\hline 1 & Very High & $156-182$ & 809 & 6.98 \\
\hline 2 & High & $131-156$ & 2595 & 22.38 \\
\hline 3 & Moderate & $105-131$ & 4032 & 34.77 \\
\hline 4 & Low & $80-105$ & 3077 & 26.54 \\
\hline 5 & Very Low & $55-80$ & 1082 & 9.33 \\
\hline
\end{tabular}

concentration was recorded. As per the standards of WHO Guidelines for Drinking Water Quality (1984), the permissible limit of nitrate in groundwater is 45 $\mathrm{mg} / \mathrm{l}$ and beyond this range it is harmful.

\section{Conclusion}

In the study, an assessment the groundwater vulnerability of the upper part of PRB using DRASTIC model was carried out. During the study, seven parameters such as depth to water table, net-recharge, aquifer media, soil media, topography, impact of

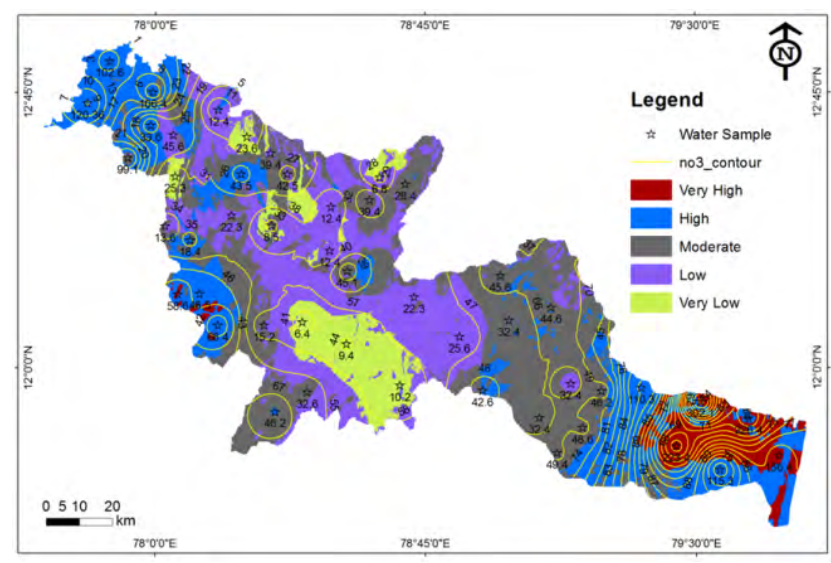

Fig. 10 DRASTIC Model with validation of nitrate concentration in the study area

the vadose zone, and hydraulic conductivity which represent the natural hydro-geological conditions of the watershed were combined in ArcGISand a groundwater vulnerable map has been prepared. The PRB the themes were integrated and classified into five categories such as very low $(9.33 \%)$, low (26.54\%), moderate (34.77\%), high $(22.38 \%)$ and very high (6.98) risk. Furthermore, Groundwater vulnerability map has been validated with nitrate concentration. This study also indicated that the GIS technique could provide an efficient way to deal with a large quantity of spatial data used in the DRASTIC model. This study gives a very comprehensive picture of vulnerability to groundwater to contamination in the area.

\section{Acknowledgment}

The author is highly thankful to Groundwater Division, Tharamani, Chennai for their guidance and to make data available to accomplish this work. Author is also grateful to Anonymous Reviewers for their useful comments to improve manuscript.

\section{References}

Al-Adamat, Rida, A.N., Foster, Ian D.L. and Baban, Serwan M.J., 2003. Groundwater vulnerability and risk mapping for the Basaltic aquifer of the Azraq basin of Jordan using GIS, Remote sensing and DRASTIC. Applied Geography, 23 (4). 303324. doi: 0.1016/j.apgeog.2003.08.007

Aller, L., T. Bennett, I.H. Lehr, and R.F. Petty, 1986. DMSTIC: A Standardized System for Evaluating Ground Water Pollution potential Using Hydrogeologic Settings, EPA/600/2-Bbl018, R.S.Kerr Environmental Research Laboratory, U. S. Environmental Protection Agency, Ada, Oklahoma.

Al-Rawabdeh AM, Nadhir A. Al-Ansari, Ahmed A. AlTaani, Fadi L. Al-Khateeb, Sven Knutsson, 2014. Modeling the Risk of Groundwater Contaminationusing Modified DRASTIC and GIS in Amman-ZerqaBasin, JordanCentral European Journal of Engineering. 4 (3), 264-280 DOI: $10.2478 / \mathrm{s} 13531-013-0163-0$

Anane, M., Abidi, B., Fethi, L., Atef, L. and Salah, J., 2013. GIS-based DRASTIC, Pesticide DRASTIC and the Susceptibility Index (SI): comparative study for evaluation of pollution potential in the NabeulHammamet shallow aquifer, Tunisia. Hydrogeol. Jour., 21, 715-731.

Antonakos, A.K., Panagopoulos, G.P. and Lambrakis, N.J., 2006. Optimization of the DRASTIC method for groundwater vulnerability assessment viathe use of simple statistical methods and GIS.Hydrogeol. Jour., v.14, pp894-911.doi:10.1007/s10040-0050008-X.

Babiker, I. S., Mohamed, A. A. M., Hiyama, T. and Kato, K., 2005. A GIS based DRASTIC model for assessing aquifer vulnerability in Kakamigahara Heights , Gifu Prefecture, central Japan. Scitotenv., 345, 127-140.

Babiker, I. S., Mohamed, A. A. M., Hiyama, T. and Kato, K., 2005. A GIS based DRASTIC model for assessing aquifer vulnerability in Kakamigahara Heights, Gifu Prefecture, central Japan. Scitotenv. 345, 127-140.

Chaturvedi, R.S., 1973. A note on the investigation of ground water resources in western districts of Uttar Pradesh in Annual Report.U.p. Irrigation Research institute. 86-122.

Dixon, B., 2005. Groundwater vulnerability mapping: A GIS and fuzzy rule based integrated tool. Appld. 
Geography, 25(4), 327-347.

Guler, C. and Ali, M., 2013. Ocean \& Coastal Management Assessment of groundwater vulnerability to nonpoint source pollution in a Mediterranean coastal zone Mersin Turkey under conflicting land use practices. Ocean \& Coastal Management, 71, 141-152. doi:10.1016/j.ocecoaman.2012.10.010

Hamza, S.M., Ahsan, A., Imteaz, M.A., Rahman, A., Mohammad, T.A. and Ghazali, A.H., 2014. Accomplishment and subjectivity of GIS-based DRASTIC groundwater vulnerability assessment method: A review. Environ. Earth Sci., 73, 30633076. doi:10.1007/s12665-014-3601-2.

Gorai, AK, Pathak, G, Iqua, J., 2014. Development of hierarchical fuzzy model for groundwater vulnerability to pollution. Arab J Geosci, DOI 10.1007/a12517-014-1417-8.

Ferreira, J. and Oliveira, J., 1997. DRASTIC groundwater vulnerability mapping of Portugal. In Groundwater: an endangered resource Proceedings of theme $\mathrm{C}$ of the27th Congress of the International Association for Hydraulic Research, San Francisco,USA.

James, W. Merchant, 1994. GIS-Based Groundwater Pollution Hazad Assessment: A Critical Review of the DRASTIC Model Photogrammetric Engineering \& Remote Sensing, 60, 9, September 1994.

O’Leary, D., Freidman J., and Pohn H., 1976. Lineaments, linear, lineation-some proposed new standards for old terms. Geological Society of America Bulletin 87, 1463-1469.

Lattman, H. and Parizek, R., 1964. Relationship between fracture traces and the occurrence of groundwater in carbonate rocks. Journal of Hydrology 2,73-91

Merchant, G., 1994. GIS-based groundwater pollution hazard assessment: a critical review of the DRASTC model, Photogramm Eng Remote Sensing 60, 1117-1127.

Secunda S.,Collin, M. and Melloul, A.J., 1998. Groundwater Vulnerability Assessment Using a Composite Model Combining DRASTIC with Extensive Land Use in Israel's Sharon Region, Journal of Environmental Management 54(1), 39-57.

Javadi, S., Kavehkar, N., Mousavizadeh, M.H. and Mohammadi, K., 2011. Modification of DRASTIC Model to Map Groundwater Vulnerability to Pollution Using Nitrate Measurements in Agricultural Areas. Jour. Agr.Sci. Tech., 13, 239249.

Jhariya, D.C., Kumar Tarun, Dewangan Rakesh, P Dharm and Dewangan P.K., 2017. Assessment of Groundwater Quality Index for Drinking Purpose in the Durg District, Chhattisgarh Using (GIS) and (MCDA) Techniques. Our. Geol. Soc. India, 89 (4), 453-459. doi:10.1007/s12594-0170628-5.

Jhariya, D.C., 2019. Assessment of Groundwater Pollution Vulnerability using GIS-based DRASTIC model and its validation using Nitrate concentration in Tandula Watershed, Chhattisgarh. Journal of Geological Society of India, 93, 567-573.

Khan, Rubia and Jhariya, D.C., 2018. Assessment of Landuse and Land cover Change and its Impact on Groundwater Quality Using Remote Sensing and GIS Techniques in Raipur City, Chhattisgarh, India. Jour.Geol. Soc. India, 92(1), 59-66.

Kumar, P, Baban, KSB, Sanjit, KD, Praveen, KT, Ghanshyam, C., 2015. Index-based groundwater vulnerability mapping models using hydrogeological settings: A critical evaluation Environmental Impact Assessment Review. 51 (2015), 38-49.

Li, J., Li, X., Lv, N., Yang, Y., Xi, B., Li, M. and Liu, D., 2015. Quantitative assessment of groundwater pollution intensity on typical contaminated sites in China using grey relational analysis and numerical simulation. Chinese Research Academy of Environmental Sciences. Environ. Earth Sci., 74, pp.3955-3968. doi: 10.1007/ s12665-014-3980-4

Mogaji, K.A., Lim, H.S. and Abdullah, K., 2013. Modeling groundwater vulnerability prediction using geographic information system GIS -based ordered weighted average OWA method and DRASTIC model theory hybrid approach. Arab Jour. Social Sciences..doi:10.1007/s12517-0131163-3.

Moghaddam, A., Fijani, A. and Nadiri, A., 2010. Groundwater Vulnerability Assessment Using GIS-Based DRASTIC Model in the Bazar an and Poldasht Plains. Jour. Environ. Studies, 35(52), 35-37.

Neshat, A. and Pradhan, B., 2015. An integrated DRASTIC model using frequency ratio and two new hybrid methods for groundwater vulnerability assessment. Nat Hazards, 76, 543-563. doi: 10.1007/s11069-014-1503-y.

Rahman, A., 2008. A GIS based DRASTIC model for assessing groundwater vulnerability in shallow aquifer in Aligarh, India, Applied Geography, 28(1), 32-53. doi:10.1016/j.apgeog.2007.07.008.

Saadeh, H.A.M. (2009) Geostatistical Assessment of Groundwater Nitrate Contamination with Reflection on DRASTIC Vulnerability Assessment:The Case of the Upper Litani Basin, Lebanon M. Water Resour Manage, 23(4), pp.775-796. doi:10.1007/s11269-008-9299-8.

Shekhar, S., Pandey, A.C. and Tirkey, A.S., 2015. A GISbased DRASTIC model for assessing groundwater vulnerability in hard rock granitic aquifer. Arab. Jour. Geosci., 8, 1385-1401. doi:10.1007/s12517014-1285-2.

Shirazi, S. M., Imran, H. M., Akib, S.,Yusop, Z. and Harun, Z. B., 2013. Groundwater vulnerability assessment in the Melaka State of Malaysiausing DRASTIC and GIS techniques. Environ. Earth Sci, 70, 2293-2304. doi: 10.1007/s12665-013- 
2360-9

Thirumalaivasan, S.K.D., 2014. GIS Based Assessment of Groundwater Vulnerability Using Drastic Model. Arabian Jour. Sci. Engg., 39(1), 207-216 doi:10.1007/s13369-013-0843-3.

Tilahun, K. and Merkel, B. J., 2010. Assessment of groundwater vulnerability to pollution in Dire Dawa, Ethiopia using DRASTIC. Environ. Earth
Sci., 59(7), 1485-1496. doi:10.1007/s12665-0090134-1.

Zhang, J, Chen Y, Zhang.S Zhang, Y, Xu, L, Qu, Z, Song, G., 2016. Comprehensive assessment and hierarchical management of the sustainable utilization of urban water resources based on catastrophe theory. Journal of the Taiwan Institute of Chemical Engineers 60, 430-437. 